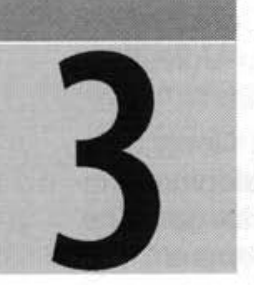

\title{
The Efficacy of Waste Management Plans in Australian Commercial Construction Refurbishment Projects
}

Mary Hardie (School of Engineering, University of Western Sydney, Australia), Shahed Khan (School of Social Sciences, University of Western Sydney, Australia), Angela O'Donnell and Graham Miller (School of Engineering, University of Western Sydney, Australia)

\begin{abstract}
Renovation and refurbishment of the existing commercial building stock is a growing area of total construction activity and a significant generator of waste sent to landfill in Australia. A written waste management plan (WMP) is a widespread regulatory requirement for commercial office redevelopment projects. There is little evidence, however, that WMPs actually increase the quantity of waste that is ultimately diverted from landfill. Some reports indicate an absence of any formal verification or monitoring process by regulators to assess the efficacy of the plans. In order to gauge the extent of the problem a survey was conducted of twenty four consultants and practitioners involved in commercial office building refurbishment projects to determine the state of current practice with regard to WMPs and to elicit suggestions with regard to ways of making the process more effective. Considerable variation in commitment to recycling policies was encountered indicating a need to revisit waste minimisation practices if the environmental performance of refurbishment projects is to be improved.
\end{abstract}

Keywords: Waste management plans, refurbishment, commercial construction, Australia.

\section{INTRODUCTION}

Australian office building markets in most major cities can be described as mature as they have a high proportion of older buildings. This is most evident in Sydney where the average age of commercial buildings is 28 years and the average time since initial construction or the last refurbishment is 19 years (Jones Lang LaSalle, 2005). On the assumption that office buildings usually require a major refurbishment every 20 to 25 years, it can be expected that commercial refurbishment activity is likely to be a significant portion of overall construction activity for the foreseeable future. In March 2006, the Sydney Central Business District contained 4.67 million square metres of office space and another 4.94 million square metres was spread throughout suburban Sydney (CB Richard Ellis Pty.Ltd., 2006). Almost 0.7 million square metres of the total was occupied by government. One of the experts interviewed for this study estimated that a 1000 square metre office refurbishment is likely to generate an average of 130 cubic metres of waste. The extent of this activity alone suggests that waste minimisation strategies for commercial refurbishment projects may have the potential to contribute to significant environment benefits and to result in a more efficient delivery of commercial office space. It should also be noted that overseas studies have demonstrated the sustainability benefits of office refurbishment when compared to new building (Anderson and Mills, 2002).

Waste Management Plans (WMPs) have been a standard requirement for most significant development in the majority of Australian local government areas for some time (McDonald and Smithers, 1998). It is not clear, however, that WMPs are having the intended environmental effect of increasing the percentage of construction waste diverted from landfill beyond the impact that market forces and social goals alone might generate. If market or social forces can drive increasing rates of reuse and recycling (Lingard et al. 2001; Lingard et al. 2000; Teo and Loosemore 2001), then it is possible that the regulatory requirement for WMPs is largely redundant.

The cost effectiveness of waste management strategies is an area that has been covered only infrequently in the construction academic literature (Mills et al. 1999; Faniran and Caban, 1998; Seydel et al. 2002). This paper reports on findings from research on waste management strategies. The research included a literature review of currently effective waste management methodologies. Following on from that research, a survey of industry experts aimed at gaining an understanding of the current state of practice in commercial building refurbishments in Australia. 


\section{POTENTIAL MECHANISMS}

\section{Pre-Demolition Audits}

The United Kingdom's Building Research Establishment uses pre-demolition audits in a system known as SMARTwaste (BRE 2006) to determine the reuse potential of construction waste (McGrath 2001). The audit process provides a list of key demolition products that can be assessed using a reclamation valuation survey. Markets are identified for recycled and recovered material, valuations given and segregation methods recommended. Audits are carried out by experienced consultants who are able to encourage 'best practice' to spread throughout the industry. The principal difficulty encountered in this approach is inaccurate documentation of the existing building which can make assessment of quantities and materials problematic (Hurley, 2004). Kwan et al. (2001) also report on work being carried out by organisations such as Construction Industry Research and Information Association (CIRIA) to develop tools for predicting and measuring waste from construction generally. While SMARTwaste and similar projects are able to operate as a nationwide system in the UK, this would be unlikely to be successfully replicated in Australia because of distances between its major urban centres, not to mention the variation between State laws. The availability of a reclamation market for a certain product in Perth, for example, would be of little use to renovators in Brisbane. A similar system in Australia would almost certainly need to be state or city based though nationally interlinked.

\section{Material Recovery Notes}

Another concept which has achieved some success in the UK is that of Material Recovery Notes (MRN). These notes represent an attempt to extend the earlier recycling industry idea of attaching Packaging Recovery Notes to reclaimed materials. MRNs encourage closed loop management of materials rather than 'one life accounting' (Hurley and Hobbs, 2003). As such they emphasise the need for manufacturers to have a salvage and recovery system in place for all items which they introduce to the market. By placing the responsibility "for the whole life cycle of a product on the product's producer MRNs encourage an eco-system approach to the built fabric of a city as envisaged by the proponents of construction ecology (Kibert 2000). While considerable advances have been made in recent years there are still several common building materials for which there are very few end of life options available in Australia. A striking example is painted plasterboard from renovations and demolitions. In Europe and North America this material issue is receiving much attention (Malin 2006) but in Australia the only current option for used plasterboard is pulverising for use as gypsum in landscaping works and even this is not a widely used practice.

\section{Key Demolition Products}

As a follow up to the success of pre-demolition audits and MRNs, the UK Department of Trade and Industry is funding a project known as BE AWARE - Built Environment Action on Waste Awareness and Resource Efficiency - which aims to help construction product manufacturers to make more efficient use of materials and processes by investigating the full range of their products' design, manufacture, installation, use and eventual disposal. Forty products are being studied in detail to see where waste can be reduced and energy saved.

A similar system has been developed in Singapore, known as the Building Waste Assessment Score (BWAS). Ekanayake and Ofori (2004) report that their ratings scheme can be used to predict waste inherent in different designs and therefore is a useful tool for contractors to use in planning for waste minimisation.

Client led initiatives can have a significant effect in this area and it is possible similarly targeted programs could be beneficial for Australian construction if encouraged and supported through government procurement programs.

\section{Simulation Software}

Chandrakanthi et al. (2002) have proposed using a simulation model to estimate the amount of waste likely to be produced by a particular project, quantify the recyclable fraction and optimise sorting procedures to ensure the practicality and profitability of recycling. The model enables the formulation of a waste plan for the project which draws on a broad spectrum of recycling information and previously achieved best practice. The accuracy of the information used ensures that waste management can be accounted for in the project schedule in a formal manner.

Shen et al. (2004) describes the process of Waste Management Mapping in a somewhat similar vein. It is demonstrated through case studies that good site management practices as well as control procedures on construction sites enables cross project comparisons. These comparisons can serve to identify areas to be targeted for improvement thereby effecting reduction of the overall volume of unrecovered waste. 


\section{Internet Sites}

In line with the advances in and widespread adoption of information and communications technology (ICT), the use of internet sites has become an expanding area in construction waste minimisation. Internet sites now serve as material exchanges to trade materials and components from demolition and refurbishment sites. In the United States there are several sites set up by city or state authorities, which can direct potential recyclers to places which advertise the sale or removal at no cost of items from buildings being demolished or refurbished. Some examples include: California Integrated Waste Management Board; West Virginia Materials Exchange; Delaware Recycling Exchange; and Kentucky Industrial Materials exchange. These are locally based materials exchange systems which not only put potential buyers and sellers in contact with each other but also spread information on recycling potential of various materials and components. It is possible that similar systems would be successful in Australia as well. It may be argued, however, that the likelihood that matches will occur between those seeking to get rid of construction material and those seeking access to second hand materials and components would be proportional to the size of the market. As such the problem of requiring a critical volume of traffic for the idea to be self perpetuating is likely to be critical in smaller centres.

In summary, a review of international literature reveals that there currently exists a considerable variety of possible techniques for improving waste management performance in construction. In order to benefit from these examples, we first need to assess the currently prevalent situation within Australia.

In Australia, the principal mechanism for managing construction waste tends to be the Waste Management Plans (WMP). The following section traces how the requirement for WMPs in the building approval process in Australia has gradually evolved in a number of places since the early 1990 s.

\section{WMPS IN AUSTRALIA}

All three levels of government in Australia have encouraged the use of WMPs and many private organisations have endorsed the practice as contributing to a more environmentally friendly construction industry.

\section{Federal Government}

One of the early initiatives driving the process of waste management was the WasteWise
Construction Program developed by the Department of the Environment which ran between 1995 and 2001 (Andrews, 1998; ABS, 2003). This program was a partnership between the Commonwealth government and major companies and associations from the building and construction industry who had volunteered to be involved. Waste Reduction Guidelines were produced by the program in 2000 . The guidelines specified as best practice both a Waste Management Plan (WMP) for a construction project as a whole, as well as WMPs for individual sub-contractors. A number of case studies were undertaken showing significantly improved rates of recycling of various materials and these case studies were publicised nationally.

\section{State Government}

At the State government level, the New South Wales Waste Minimisation and Management Act 1995 provided a state-wide framework for waste minimisation generally. Regional Waste Boards were initiated to focus on various industries. A high level of construction activity leading up to the 'green' Olympic Games staged in Sydney in 2000 maintained a focus on waste minimisation. The 1995 Act was replaced by the Waste Avoidance and Resource Recovery Act of 2001, which established Resource NSW, in place of the earlier NSW Waste Boards and the State Waste Advisory Council. In 2003, Resource NSW was incorporated into the NSW Department of Environment and Heritage. One of the overall results of these legislative changes has been that in New South Wales, the process of obtaining development approval for building works now generally requires the submission of a Waste Management Plan. Depending on the size of the building project and the consent authority (body approving the application), the Waste Management Plan can take various forms. However, some kind of WMP is required for almost all non-residential projects which trigger the requirement of a development approval.

Similar policy time frames are reflected in the other states. The Victorian Government established EcoRecycle Victoria in 1996. EcoRecycle published a "Waste Wise Construction and Demolition Kit" in 2004 which included waste minimisation plans. In 2005 the Victorian Government released a "Towards Zero Waste Strategy". Also, in 2005, EcoRecycle Victoria merged with the Sustainable Energy Authority of Victoria to form Sustainability Victoria. There appears to be some disquiet among committed recyclers in both NSW and Victoria about the apparent downgrading of the priority given to waste minimisation as evidenced 
by stand alone waste authorities being merged with larger, less targeted bodies.

The Queensland State Government introduced the "Waste Management Strategy for Queensland" in 1996. This strategy specified a waste recovery program be in place for any government building developments. In 1996, the Australian Capital Territory launched "No Waste by 2010 - A Waste Management Strategy for Canberra". In 1999 the "Development Control Code for Best Practice Waste Management" came into place. Zero Waste South Australia was established in 2003 to assist local councils in waste planning and to establish regional waste management strategies. There have been comparable developments in the other states and territories.

\section{Local Government}

Local government organisations have not been slow with their own initiatives. In 1995, the Western Sydney Regional Organisation of Councils developed a standard Waste Not DCP (Development Control Plan) as a tool for reducing construction and demolition waste during building projects. Most local councils have produced their own preferred format of WMP to be submitted with an application for Development Approval. There is little consistency in format or content required. Most councils also have extensive waste policies which indicate preferred practices. A recent example is the Council of the City of Sydney's extensive Policy for Waste Minimisation in New Developments, including Waste Management Plan templates for the demolition phase, construction phase and use of premises phase.

\section{Other Organisations}

The establishment of various rating systems for buildings has added further impetus to the move towards WMPs. The Green Building Council of Australia was established in 2002 and introduced the Green Star Environmental rating for buildings soon after. Internationally other green building councils are developing under the auspices of the World Green Building Council established in 1998.

As the above discussion suggests, WMPs have become the standard means of regulating construction waste minimisation in Australia. However, they seem to have been widely adopted despite there being little objective evaluation of their effectiveness as a tool to achieve improved levels of reuse and recycling in the industry. Meanwhile, considerable incentive nevertheless exists to divert waste from landfill and some of the drivers of such a move are listed in the following section

\section{CURRENT DRIVERS}

Rising waste levies are currently providing an incentive to divert waste from landfill particularly in the more highly populated states. Table 1 shows a comparison of the four largest states. In general, potential cost effects of minimising waste are proving to be greater as the cost of disposal to landfill increases. Some of the rates shown represent sharp increases over recent years and the NSW administration, in particular, appears to be using the price mechanism to drive increased reuse and recycling. This is despite evidence from the UK Landfill Tax indicating that levies on waste sent to landfill have been largely ineffective in driving changes in waste management behaviour in construction (Martin and Scott, 2003).

At the same time, however, as the price of landfill is increasing there has been a growth in the use of the various green rating schemes for commercial buildings. Increasingly companies are seeking to be listed on sustainable and ethical indexes and there is a consequent desire for 'green buildings'. This trend is also evidenced in the current federal Productivity Commission's Public Inquiry into Waste Generation and resource Efficiency (Australian Government Productivity Commission 2006). The inquiry is not specific to the construction industry, however, a number of submissions have been made to the Inquiry from the construction sector.

\begin{tabular}{|l|l|l|l|l|l|}
\hline State & NSW & Victoria & Queensland & W. Australia & S. Australia \\
\hline Metropolitan & $\$ 30.40 /$ tonne & $\$ 13.00 /$ tonne & $\$ 0$ & $\$ 3.00 /$ tonne $^{1}$ & $\$ 10.80 /$ tonne $^{-}$ \\
\hline Rural & $\$ 23.10 /$ tonne & $\$ 11.00 /$ tonne & $\$ 0$ & $\$ 0$ & $\$ 5.40 /$ tonne \\
\hline
\end{tabular}

Table 1 - Waste Levies for Construction and Demolition Waste by State ${ }^{2}$

${ }^{1}$ levy applies to putrescible waste; ${ }^{2}$ As at July 2006 - Source Productivity Commission Draft Report 
This reflects the fact that the construction and demolition industry accounts for $42 \%$ of solid waste generation in Australia (Productivity Commission Draft Report, 2006 pg17).

In recent years, industry bodies have also taken a strong interest in waste minimisation. For example, the Australian Institute of Building has published both a Corporate Statement of Commitment to waste reduction and a Waste Minimisation Code of Practice for members. Similarly, the list of criteria for judging the annual Professional Excellence Awards now includes waste minimisation,

From the above discussion it can be seen that the issue of construction waste figures prominently on the public agenda, and Waste Management Plans have been required for most construction projects since the mid 1990's. Despite the widespread use of WMPs in their many formats there has been very little research into their efficacy with regard to realising their principle aims. Anecdotally, there is some dissatisfaction with the system and considerable scepticism within the industry about the value of WMPs in general.

It was in this context that it was decided to test the validity of WMPs by means of an expert survey of individuals involved in current commercial refurbishment projects.

\section{THE SURVEY}

Twenty one expert individuals associated with the commercial refurbishment sector of the construction industry were interviewed (see Table 2). Purposive sampling was used to enable quick identification of individuals and firms most likely to have recent experience in the area of commercial refurbishment. This method captures the opinions of the target population effectively but has the disadvantage of a likely bias towards those respondents who are readily accessible. As a counter measure to this tendency respondents were deliberately sought from outside the home base of the researchers. The experts selected were based in NSW, Victoria, Queensland and the ACT.

Most had interstate experience and one had national responsibility for waste management issues in a large construction/property corporation. Most of the experts had more than ten years experience in the construction industry with fifty percent having more than twenty years experience. Those with fewer than ten years experience tended to be in positions such as site manager where they had day to day contact with waste minimisation issues. The expert group included seven consultants from the professions of quantity surveying, architecture, engineering and environmental consultancy and fourteen contractors whose positions ranged from senior project managers to site managers to environment and $\mathrm{OH} \& \mathrm{~S}$ managers for large and medium construction companies. One third of the twenty one respondents had worked on more than twenty multi storey commercial building refurbishments. In addition to the twenty one construction industry interviews, three expert waste contractors were surveyed specifically about their knowledge of waste from commercial construction and demolition. The interviews covered a wide range of topics including several facets of waste management as it affects the commercial construction sector. Of the twenty four experts surveyed, ten involved face-to-face meetings, twelve were conducted by telephone and two were conducted through email. Face-toface interviews/surveys were recorded and transcripts prepared as well as notes taken by the interviewer. A number of the questions specifically referred to Waste Management Plans while others dealt with related topics. This study centres on responses to those specific WMP questions. Some difficulty was experienced with getting numerical or hard answers from the experts with most of them stressing the need to qualify any specific answers according to individual project circumstances. Qualifying comments were recorded for each survey answer. 


\begin{tabular}{|c|c|c|c|c|}
\hline \# & Job Title/Profession & Industry Sector & $\begin{array}{l}\text { Years in } \\
\text { Construction }\end{array}$ & State Base \\
\hline 1 & Director & Consultant & $11-20$ & NSW \\
\hline 2 & Project Manager & Contractor & $11-20$ & VIC \\
\hline 3 & Executive Director & Contractor & $11-20$ & NSW \\
\hline 4 & Project Officer & Consultant & $0-5$ & NSW \\
\hline 5 & Program Manager & Consultant & $>20$ & NSW \\
\hline 6 & Manager & Contractor & $6-10$ & NSW \\
\hline 7 & Estimator & Contractor & $>20$ & QLD \\
\hline 8 & Manager & Contractor & $>20$ & NSW \\
\hline 9 & Manager & Contractor & $11-20$ & QLD \\
\hline 10 & Director & Contractor & $>20$ & VIC \\
\hline 11 & Senior Associate & Consultant & $>20$ & QLD \\
\hline 12 & Director & Consultant & $>20$ & NSW \\
\hline 13 & Site Manager & Contractor & $>20$ & NSW \\
\hline 14 & $\begin{array}{l}\text { Senior Project } \\
\text { Manager- }\end{array}$ & Contractor & $>20$ & NSW \\
\hline 15 & Director & Consultant & $>20$ & NSW \\
\hline 16 & Associate & Consultant & $>20$ & VIC \\
\hline 17 & $\begin{array}{l}\text { National OHS\&E } \\
\text { Manager }\end{array}$ & Contractor & $>20$ & ACT \\
\hline 18 & $\begin{array}{l}\text { State Building Group } \\
\text { Manager }\end{array}$ & Contractor & $>20$ & NSW \\
\hline 19 & Project Engineer & Waste Contractor & $6-10$ & QLD \\
\hline 20 & State Manager & Waste Contractor & $11-20$ & NSW \\
\hline 21 & $\begin{array}{l}\text { State OHS\&E } \\
\text { Coordinator }\end{array}$ & Contractor & $6-10$ & VIC \\
\hline 22 & EH\&S Manager & Contractor & $>20$ & NSW \\
\hline 23 & Builder/Manager & Waste Contractor & $0-5$ & NSW \\
\hline 24 & $\begin{array}{l}\text { Safety \& Environment } \\
\text { Manager }\end{array}$ & Contractor & $11-20$ & NSW \\
\hline
\end{tabular}

Table 2- Survey participant details 


\begin{tabular}{|c|c|c|c|}
\hline \multirow[t]{2}{*}{$\#$} & How often WMPs required & $\begin{array}{l}\text { How often WMPs } \\
\text { monitored }\end{array}$ & \multirow[t]{2}{*}{ How monitored or referred to? } \\
\hline & $\%$ & $\%$ & \\
\hline 1 & 100 & 0 & In house (less than 1\%) \\
\hline 2 & $25-29$ & 100 & For green rating \\
\hline 3 & * & * & By Council \\
\hline 4 & $1-24$ & $1-24$ & They are not/lip service only \\
\hline 5 & $1-24$ & $1-24$ & They are not/ lip service only \\
\hline 6 & 100 & 0 & They are not/ lip service only \\
\hline 7 & 0 & 0 & They are not/lip service only \\
\hline 8 & 100 & 100 & In house/ externally audited \\
\hline 9 & $1-24$ & 100 & In house \\
\hline 10 & 0 & ${ }^{*}$ & They are not/lip service only \\
\hline 11 & 0 & 0 & They are not/lip service only \\
\hline 12 & $1-24$ & $1-24$ & For green rating \\
\hline 13 & 100 & $50-74$ & In house \\
\hline 14 & $75-99$ & $75-99$ & In house \\
\hline 15 & * & $1-24$ & They are not/lip service only \\
\hline 16 & 100 & 100 & Through Quality Assurance \\
\hline 17 & $1-24$ & $1-24$ & They are not/lip service only \\
\hline 18 & 100 & 100 & Through Quality Assurance \\
\hline 19 & * & 0 & They are not/ lip service only \\
\hline 20 & * & * & No comment \\
\hline 21 & 100 & 100 & In house \\
\hline 22 & 100 & 100 & In house \\
\hline 23 & * & 0 & They are not/lip service only \\
\hline 24 & $1-24$ & $1-24$ & Externally audited \\
\hline
\end{tabular}

Table 3 - Waste Management Plan Experience [ ${ }^{\star}$ Unable to quantify] 


\section{Waste Management Plan Efficacy}

Generally the responses received from the expert interviewees showed a broad divergence in attitudes and priorities with regard to waste minimisation. Some experts specifically saw themselves as having the role of promoting reuse and recycling of construction material. These tended to be either the environmental consultants or managers charged by their companies with particular responsibility for environmental matters. Other respondents, especially construction and site managers among the contractor group, stressed that their main driver with respect to waste management was profitability. They suggested they would readily take up any recycling initiatives which could be proven to pay for themselves.

On the relatively simple question of how often do you see WMPs required for commercial refurbishment projects there was a surprisingly wide spread of answers from the expert respondents with a skew towards each end of the distribution. In other words, very few respondents gave answers in the middle of the range. The responses exhibited a bipolar distribution with approximately similar numbers saying that WMPs were required for all projects as those who said they were not required or rarely required. Specifically $38 \%$ of respondents said that WMPs were required for all the commercial refurbishment projects that they had been involved with and a surprisingly comparable $38 \%$ of expert respondents said that WMPs were either not required at all or required in less than $25 \%$ of cases. It may be that the latter respondents were thinking of fully internal refurbishment projects with no external construction work involved. These projects may sometimes be treated as fully internal matters which may not require Development Approval and therefore there would be no legal requirement for a WMP.

The three waste contractors among the experts were asked whether the Waste Management Plans required by Councils for commercial construction projects had affected their own reporting regimes. Two of the experts answered in the negative. The third waste contractor stated that his 'tier one customers', that is, publicly listed companies, always required reporting. However for 'tier 2 and 3 customers', the requirement for reporting waste management would average out at $50 \%$. The contractor stressed that the Waste Management Plans were always compiled in consultation with the project developers.

The survey indicated that, in some quarters at least, the WMP is regarded merely as compliance paperwork which has no real effect on outcomes. While the requirement to produce a WMP may have some initial educative value, their continued production for each new project without a system of feedback or evaluation is unlikely to have significant ongoing positive effect.

\section{Waste Levies}

There was no significant correlation between respondents coming from the state of New South Wales where considerably higher waste levies are in place (as shown in Table 1) and the prevalence of the use of WMPs or the rate at which they are monitored. This in itself indicates that the cost of sending waste to landfill is not yet a significant driver of waste minimisation practice. Only one respondent nominated waste levies as a significant incentive to waste minimisation. By contrast $67 \%$ of respondents nominated cost as the principle incentive for engaging in reuse or recycling practices on their building projects. When questioned further on the topic it was indicated that many favoured recycling efforts that resulted in a net return in dollar terms rather than a reduction in fees like waste levies which they regarded as overheads.

\section{Monitoring}

Those respondents who said that WMPs were required for $100 \%$ of their projects were also very likely to have strong in house monitoring of waste processes. None of the interviewees reported an effective process of monitoring WMPs by local councils and $39 \%$ of respondents reported that WMPs were not monitored at all in any effective way. The remainder of those surveyed $(61 \%)$ reported various systems of in house monitoring based on site records, tip receipts, monthly returns, QA evaluation systems or Green Star rating requirements. Several of the interviewees reported the use of more than one of these monitoring processes. Minimal external auditing was reported other than that required for 'green ratings'. One consultant referred to stories of builders using a single waste management plan for all projects without any modification for the individual construction job - "some builders put the same Waste Management Plan in to Council every time and don't even change the figures". 
There was no evidence of an industry consensus on the best system for monitoring and tracking waste on commercial refurbishment projects. There was, however, considerable scepticism about the current regulatory system and its inability to deliver productive outcomes. No consensus existed on a standard method of measuring waste outcomes in order to make cross project comparisons. Only one out of twenty one construction industry experts surveyed reported that his company collected data on waste outcomes from their projects in order to produce a baseline record for future projects.

Suggestions from the respondents to improve the current situation included imposition of uniform requirements across local government areas, encouraging good waste record keeping on site, spot checks for verification of records and some form of third party audit to ensure the integrity of the data on which the system is based.

\section{Incentives to Waste Minimisation}

Simple cost incentive seems to be the main reason why the greater quantity ( 80 to $100 \%$ ) of intrinsically valuable metallic items from construction waste are commonly recovered. Similarly concrete and other bulky materials are being increasingly recycled because the recycling process can be shown to generate net savings. Being cost neutral, however, was often not regarded by contractors as sufficient incentive for a recycling effort unless green ratings or other external auditing systems were involved (See table 4)

On construction sites waste is measured either by weight or by volume or by number of skips depending on the circumstances. As a consequence there is little in the way of standardised project data which can be used to build historical records of reuse and recycling rates in commercial refurbishments. Establishing performance benchmarks is an area where considerable research needs to be done.

Without such research and the establishment of benchmarks it is difficult to see WMPs having any effect other than a cosmetic one in terms of the overall management of the construction and demolition waste stream. Specifically little improvement is likely to be generated on the complex waste management of refurbishment projects.

\section{CONCLUSION}

An ethos of participation is essential for sustainable waste management. If waste management plans are regarded as mere formalities required for council approval, then little is achieved by insisting on their production for each new project. They may of course have an educational effect at least initially. They may work as a consciousness raising tool and indeed local councils may see this as their principal purpose. It is evident, however, that they do not act as an effective means of estimating, measuring, monitoring and tracking waste outcomes from commercial refurbishments. This study indicates that making improvements in the sustainability of waste management on projects is either done at the instigation of responsible construction companies with committed clients or else it is largely not done at all. Regulatory authorities do not have the time or the personnel to do ongoing monitoring of outcomes from projects.

The renovation and refurbishment of commercial buildings is likely to increase as a portion of overall construction and consequently remain a significant generator of waste sent to landfill. If the environmental performance of the sector is to be improved then new mechanisms will need to be found to encourage recycling and reuse and discourage sending large amounts of bulky material to landfill sites. It is evident that so far waste levies have had little effect on the quantities of material diverted from landfill. Nevertheless there is a willingness to change processes if the change is beneficial to a project's profitability. The industry and researchers need to cooperate to develop new standardised and transparent systems for tracking the outcome of the construction process. In addition there is a need for information on best practice waste minimisation techniques to be broadly spread throughout the industry. One of the drivers for this sort of information diffusion is likely to be the increased use of the internet by construction companies. An opportunity exists for a portal which brings people with a need for recycled material into contact with those who renovate and demolish buildings. Such processes can assist in closing the loop on the construction cycle by making refurbishment and demolition by-products the feedstock for new 


\begin{tabular}{|c|c|c|}
\hline$\#$ & $\begin{array}{l}\text { Real incentives for minimising waste on } \\
\text { commercial refurbishment projects? (Open } \\
\text { ended question) }\end{array}$ & $\begin{array}{l}\text { "Government policy has led to better } \\
\text { levels of waste minimisation carried } \\
\text { out on commercial refurbishment } \\
\text { projects?" }\end{array}$ \\
\hline 1 & Regulation and waste levies & Strongly agree \\
\hline 2 & Client driven & Agree \\
\hline 3 & Profitability & Neutral \\
\hline 4 & Regulation and Profitability & Neutral \\
\hline 5 & Profitability & Disagree \\
\hline 6 & $\begin{array}{l}\text { Profitability, government work and green } \\
\text { ratings }\end{array}$ & Agree \\
\hline 7 & Profitability & Strongly agree \\
\hline 8 & Profitability & Agree \\
\hline 9 & Green ratings & Disagree \\
\hline 10 & Client driven & Disagree \\
\hline 11 & Profitability and Green ratings & Agree \\
\hline 12 & Profitability & Agree \\
\hline 13 & Profitability & Agree \\
\hline 14 & Profitability & Agree \\
\hline 15 & Profitability & Agree \\
\hline 16 & Profitability & Disagree \\
\hline 17 & Regulation, client driven and Profitability & Disagree \\
\hline 18 & Regulation & Strongly agree \\
\hline 19 & Profitability & Disagree \\
\hline 20 & There are none & Disagree \\
\hline 21 & Profitability & Agree \\
\hline 22 & Regulation & Agree \\
\hline 23 & Resale value of materials & Strongly agree \\
\hline 24 & Regulation & Agree \\
\hline
\end{tabular}

Table 4 - Waste Minimisation Incentives

\section{REFERENCES}

Anderson, J., and Mills, K. (2002). "Refurbishment or redevelopment of office buildings? Sustainability comparisons." BRE, London.

Andrews, S. (1998). "Waste Wise Construction Program Review: A report to ANZECC." Commonwealth Department of the Environment, Canberra.

Australian Bureau of Statistics. (2003). "The WasteWise construction program." ABS Yearbook 2003, 620-622.

Australian Government Productivity Commission. (2006). "Waste Management, Draft Report." Canberra.
Building Research Establishment. (2006). "SMARTwaste." BRE. Available at http://www.smartwaste.co.uk/ Accessed $3^{\text {rd }}$ August 2006.

CB Richard Ellis Pty Ltd. (2006). "Market View Sydney Metropolitan Office." M. Ciesielski, ed. Available http://www.cbre.com.au/research/MarketView/ sydney/ Accessed $3^{\text {rd }}$ August 2006.

Chandrakanthi, M., Hettiaratchi, P., Prado, B., and Ruwanpura, J. Y. (2002)."Optimization of the waste management for construction projects using simulation." Simulation Conference, 2002. Proceedings of the Winter, 1771-1777 
Council of the City of Sydney. (2005). "Policy for Waste Minimisation in New Developments." Available http://www.cityofsydney.nsw.gov.au/Developm ent/PlanningControlsConditions/Development Policies.asp\#link253 Accessed $3^{\text {rd }}$ August.

Faniran, O. O., and Caban, G. (1998). "Minimizing waste on construction project sites." Engineering, Construction and Architectural Management, 5(2), 182-188.

Hurley, J. (2004). "Valuing the Predemolition Audit." Deconstruction and Building Materials Reuse Conference, Oakland California.

Hurley, J., and Hobbs, G. (2006). "UK Country Report on Deconstruction." Deconstruction: Techniques, Economics, and Safety, C. J. Kibert, A. Chini, and C. Hendriks, eds.

Jones Lang LaSalle. (2005). "Building Refurbishment - Repositioning Your Asset for Success." Available at http://www.joneslanglasalle.com.au/en$\mathrm{gb} /$ research/researchabstract?artid $=1749$ Accessed $3^{\text {rd }}$ August 2006.

Kibert, C. J., Sendzimir, J. and Guy, B. (2000). "Construction ecology and metabolism: natural analogues for a sustainable built environment." Construction Management and Economics, 18(8), 903-916.

Kwan, J., Mallett, H., Mason, S., and Spencer, D. (2001). "Tools for measuring and forecasting waste generated on site. Scoping study (PR083)." CIRIA, London.

Lingard, H., Gilbert, G., and Graham, P. (2001). "Improving solid waste reduction and recycling performance using goal setting and feedback." Construction Management \& Economics, 19(8), 809-817.

Lingard, H., Graham, P., and Smithers, G. (2000). "Employee perceptions of the solid waste management system operating in a large Australian contracting organization: implications for company policy implementation." Construction Management and Economics, 18(4), 383-393.

Malin, N. (2006). "Wallboard Recycling Monster Arrives from Europe." Green Source, McGraw Hill Construction.

Martin, A., and Scott, I. (2003). "The Effectiveness of the UK Landfill Tax." Journal of Environmental Planning and Management, 46(5), 673 - 689.

McDonald, B., and Smithers, M. (1998). "Implementing a waste management plan during the construction phase of a project: $A$ case study." Construction Management and Economics, 16(1), 71-78.

McGrath, C. (2001). "Waste minimisation in practice." Resources, Conservation and Recycling, 32(3-4), 227-238.

Mills, T. H., Showalter, E., and Jarman, D. (1999). "Cost-effective waste management plan." Cost Engineering, 41(3), 35-43.

Seydel, A., Wilson, O. D., and Skitmore, R. M. (2002). "Financial Evaluation of Waste Management Methods: A Case Study." Journal of Construction Research, 3(1), 167179.

Shen, L. Y., Tam, V. W. Y., Tam, C. M., and Drew, D. (2004). "Mapping Approach for Examining Waste Management on Construction Sites." Construction Engineering and Management, 130(4), 472-481.

Teo, M. M. M., and Loosemore, M. (2001). "A theory of waste behaviour in the construction industry." Construction Management \& Economics, 19(7), 741-751.

Zhou, X. (1993). Occupational Power, State Capacities, and the Diffusion of Licensing in the American States: 1890 to 1950 , American Sociological Review, 58(4), pp 536-552. 